\title{
Tax Concessions and Investment Behaviour
}

\author{
QAZI MASOOD AHMED and S. MOQUET AHSAN
}

\section{INTRODUCTION}

The Government of Pakistan, like many other developing countries, has opted for tax holidays as an important fiscal measure to encourage rapid industrialisation in the backward areas. This concession is also supplemented by several other economic and non-economic measures including import duty, and depreciation allowances. Mintz (1990) discusses the efficacy of tax holidays in the presence of accelerated depreciation allowances concludes that tax holidays which are designed to increase capital formation may end up penalising capital formation. Mintz's (1990) conclusion is based on the assumption that if the assets are long-lived, and the income tax system allows deductibility of accelerated depreciation but cannot be deferred, then the tax holidays, by preventing depreciation deduction in the early period may actually penalise investment during the tax holiday period. If on the other hand the depreciation allowance is deferred till the end of tax holiday period, the tax system is genuinely generous and provides a real incentive for capital formation.

In Pakistan the tax code are such that the firms in the tax holidays region are not allowed to claim or defer accelerated depreciation allowance but can claim normal depreciation allowance only after the expiry of tax holidays period. Whereas the firms in developed areas can claim both accelerated (25 percent) and normal depreciation allowances (10 percent) annually. Import duty concession is given for most of the underdeveloped areas and few of the developed areas.

These different sets of incentives affects the cost of capital and hence investment differently. The purpose of the present paper is to see these effects by computing the cost of capital for developed and under developed areas. This will help us to examine whether the tax holidays as an incentive is effective or act as a barrier to claim other generous concession like the depreciation allowance.

With this introductory section, the organisation of the remaining paper is as follow, Section I discuss the theoretical framework of the paper and Section II described the data. Section III discuss the results followed by Section IV on the conclusion and policy implications.

Qazi Masood Ahmed and S. Moquet Ehsan are affiliated with Applied Economics Research Centre, Karachi, respectively. 


\section{THEORETICAL FRAMEWORK}

The present study investigate the nature of investment in the industrial estate induced by the tax holidays and other fiscal concessions-whether the concession has really led to new investment in the economy — or whether the concessions have just been enjoyed as a windfall gain by those firms that would have invested even in their absence. This in turn will help to examine the efficacy of the tax holiday in relation to other concessions. For this purpose we will conduct a case study of an industrial estate, Gadoon Ama Zai, located in the North West Frontier Province (NWFP). This estate was established in 1988-89 fiscal year. The study is based on a survey conducted by the Applied Economics Research Centre, Karachi, in 1993.

In order to find the nature of investment the basic investment appraisal criterion, the Net Present Value of the discounted revenue streams, will be used. The net present value in the backward areas will be calculated on the basis of the ex-ante annualised calculation, since little ex-post information were collected.

The computation requires the following steps;

- Computation of profitability of a project in underdeveloped area.

- Computation of cost disadvantage in underdeveloped area in relation to developed area.

- Computation of profitability of a project in a developed area.

- Computation of the Break-up value of a project.

First we assign the following symbols to the variables, which will be discussed in the following section.

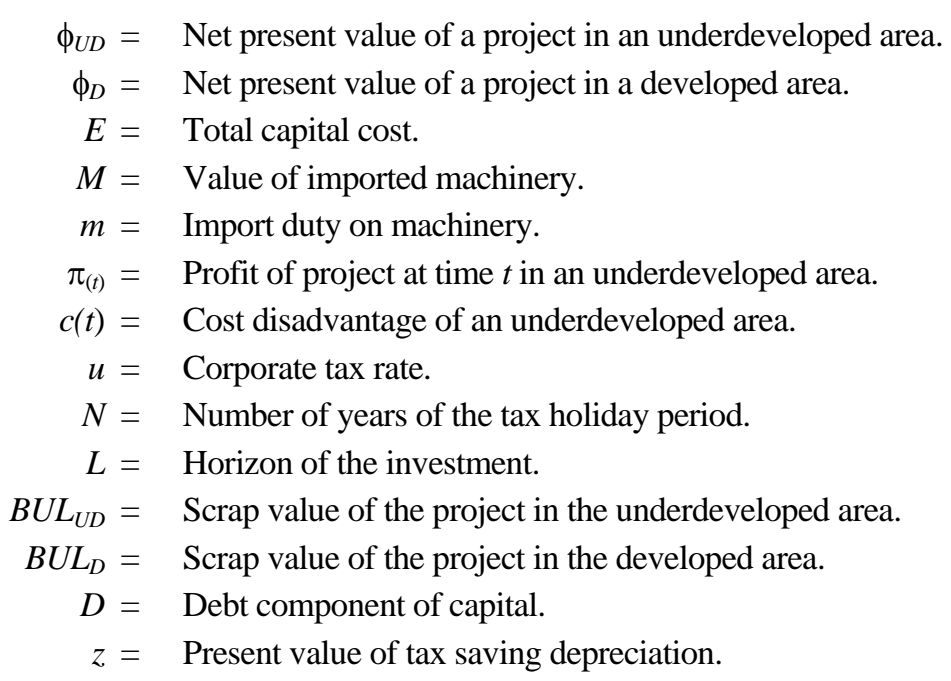

We will discuss three different scenarios of fiscal concession to compute the net 
present value of a project in the developed and underdeveloped area.

\section{- Scenario I}

The net present value of a project in a developed area when neither tax holidays nor the import duty are given. In this case the present value of a project may be defined as follows:

$$
\phi_{D}=-[E+M m]+(1-u) \int_{0}^{L} e^{-r t}[\pi(t)+C(t)] d t \quad \ldots \quad \ldots
$$

where;

$$
\begin{aligned}
\phi_{D} & =\text { Net present value in developed area. } \\
-[E+M m] & =\text { Capital cost plus import duty in developed area. } \\
(1-u) \int_{0}^{L} e^{-r t}[\pi(t)+C(t)] d t= & \text { Present value of net after tax profit in a developed area. } \\
B U V_{D} e^{-r L}= & \text { Present value of the scrap value of the project in a } \\
& \text { developed area at the end of the period. } \\
u z= & \text { Present value of tax saving depreciation allowances. }
\end{aligned}
$$

\section{- Scenario II}

The net present value of a project in an underdeveloped area when only tax holiday is granted, will be computed as follows;

$$
\begin{aligned}
& \phi_{U D}=-[E+M m]+\int_{0}^{N} \pi(t) e^{-r t} d t+(1-u) \int_{N}^{L}\left[\pi(t) e^{-r t}\right] d t \\
& \begin{array}{lllll}
+B U V_{U D} e^{-r L}+u Z & \ldots & \ldots & \ldots & \ldots
\end{array}
\end{aligned}
$$

where,

$$
\begin{aligned}
\phi_{U D} & =\text { Net present value in underdeveloped area. } \\
{[E+M m] } & =\text { Capital cost in underdeveloped area. } \\
\int_{0}^{N} \pi(t) e^{-r t} d t & =\text { Present value of net profit during tax holiday period. } \\
(1-u) \int_{N}^{L}\left[\pi(t) e^{-r t}\right] d t= & \text { Present value of net profit after tax holiday period. } \\
B U V_{U D} e^{-r L}= & \text { Present value of the scrap value of project in underdeveloped } \\
& \text { area at the end of the project. } \\
u z= & \text { Present value of tax saving depreciation allowances. }
\end{aligned}
$$

\section{- Scenario III}

The net present value of a project in the underdeveloped area when both 
concessions i.e. tax holiday and import duty are granted, would be computed as follows:

$$
\phi_{U D}=-E+\int_{0}^{N} \pi(t) e^{-r t} d t+(1-u) \int_{N}^{L}\left[\pi(t) e^{-r t}\right] d t+B U V_{U D} e^{-r L}+u z \quad \ldots
$$

where,

$$
\begin{aligned}
\phi_{U D} & =\text { Net present value in an underdeveloped area. } \\
-E & =\text { Capital cost in an underdeveloped area. } \\
\int_{0}^{N} \pi(t) e^{-r t} d t & =\text { Present value of net profit during the tax holiday period. } \\
(1-u) \int_{N}^{L} \pi\left[(t) e^{-r t}\right] d t= & \text { Present value of net profit after tax holiday period. } \\
B U V_{U D} e^{-r L}= & \text { Present value of the scrap value of the project in } \\
& \text { underdeveloped area at the end of the time period. } \\
u z= & \text { Present value of tax saving depreciation allowances. }
\end{aligned}
$$

From Equations 1 and 2 we can compute the difference in the net present value of projects in two areas.

$$
\left(\phi_{U D}-\phi_{D}\right)=u \int_{0}^{N} \pi(t) e^{-r t} d t-(1-u) \int_{0}^{L} C(t) e^{-r t} d t \quad \ldots \quad \ldots
$$

where,

$$
\begin{aligned}
\left(\phi_{U D}-\phi_{D}\right)= & \begin{array}{l}
\text { Difference between net present value in underdeveloped and } \\
\text { developed areas. }
\end{array} \\
\int_{0}^{N} \pi(t) e^{-r t} d t= & \text { Present value of net profit due to tax holiday. } \\
(1-u) \int_{0}^{L} C(t) e^{-r t} d t= & \text { Present value of net profit due to the cost disadvantage of } \\
& \text { underdeveloped area. }
\end{aligned}
$$

Similarly from Equations 1 and 3 the difference in the net present value of the project in underdeveloped and developed areas are,

$$
\begin{aligned}
& \left(\phi_{U D}-\phi_{D}\right)=m M+u \int_{o}^{N} \pi(t) e^{-r t} d t-(1-u) \int_{0}^{L} C(t) e^{-r t} d t \quad \ldots \quad \ldots \\
& -(1-u) \int_{0}^{L} C(t) e^{-r t} d t
\end{aligned}
$$

where,

$$
\begin{aligned}
\left(\phi_{U D}-\phi_{D}\right)= & \text { Difference between net present value in the developed and } \\
& \text { underdeveloped area. } \\
M m= & \text { Value of the exemption of import duty on machinery. } \\
\int_{0}^{N} \pi(t) e^{-r t} d t= & \text { Present value of the net profit due to the tax holiday. }
\end{aligned}
$$


$(1-u) \int_{0}^{L} C(t) e^{-r t} d t=$ Present value of the net profit due to the cost advantage of developed area.

The following hypothesis can be inferred from Equations 4 and 5 .

1. $\frac{\partial\left(\phi_{U D}-\phi_{D}\right)}{\partial N}>0$

This implies that the longer the period of the tax holiday, the larger would be the difference in the net present value of the two projects.

2. $\frac{\partial\left(\phi_{U D}-\phi_{D}\right)}{\partial \pi}>0$

This hypothesis states that the difference in the net present value in two areas increases with the profits due to the tax holiday or import duty or both.

3. $\frac{\partial\left(\phi_{U D}-\phi_{D}\right)}{\partial C(t)}>0$

This states that the greater the disadvantage of cost in the underdeveloped area, the greater would be the difference in net present value in the two areas.

4. $\frac{\partial\left(\phi_{U D}-\phi_{D}\right)}{\partial M}>0$

This states that the higher the component of imported machinery, the larger would be the difference in cost, assuming machinery import is tax exempted.

5. $\frac{\partial\left(\phi_{U D}-\phi_{D}\right)}{\partial m}>0$

This states that the higher the import duty on machinery, the larger would be the difference in the present value of project in between the two areas.

If the net present value of a project is less than zero in the developed area, but greater than zero in the underdeveloped area with a fiscal incentive, we would conclude that the investment is 'generated'.

$\phi_{U D}>0>\phi_{D}$

This implies that investment would not take place, if the fiscal incentives were not 
offered in the backward areas. This would also show that incentives have successfully increased investment in the backward areas.

If on the other hand the net present value of a project is positive in both developed and underdeveloped areas and furthermore, the net present value of a project in an underdeveloped area is more than the net present value of the project in the developed area, then the investment would be "diverted" investment.

$$
\phi_{U D}>0 \quad \phi_{D}>0
$$

and

$$
\phi_{U D}>\quad \phi_{D}>0
$$

This implies that the investment would also have taken place in the developed area even without the fiscal incentive. This investment has taken place in the underdeveloped area because of these fiscal incentives. This means that this investment has been diverted from a developed area.

\section{DESCRIPTION OF THE DATA}

The purpose of this sub-section is to give a brief description of the final variables which have been used in the analysis. These variables are discussed in detail in Appendix 2.

(a) Profit in the underdeveloped areas. The profit of a firm in underdeveloped areas is equal to the difference between sales and the total cost of production and marketing.

(b) Cost disadvantage of underdeveloped area. This has been derived by subtracting the total cost in the underdeveloped areas and developed areas. It shows the additional cost to produce and market the product in the underdeveloped area.

(c) Rate of discount: In is assumed to be 12.5 percent (bank rate) in order to analyse the variables.

(d) Profit in developed areas: The profit in developed areas is equal to the profit in underdeveloped areas plus the cost disadvantage of underdeveloped area.

(e) Capital cost: Total capital cost includes the value of imported machinery and domestically produced machinery.

(f) Net present value in underdeveloped area: The net present value of a project when both tax holiday and import duty concessions are granted in an underdeveloped area is:

$$
\begin{aligned}
N P V_{U D}= & (\text {-capital cost })+\text { Profit in underdeveloped area } \\
& + \text { Tax saving depreciation + Scrap value }
\end{aligned}
$$


When only a tax holiday is granted, the net present value would be computed as follows:

$$
\begin{aligned}
N P V_{U D}= & -(\text { capital cost }+ \text { import duty })+\text { profit in underdeveloped area } \\
& + \text { Tax saving depreciation }+ \text { Scrap value }
\end{aligned}
$$

(g) Net present value in developed area: The net present value of the project in a developed area would be computed as follows:

$$
\begin{aligned}
N P V_{D}= & -(\text { capital cost }+ \text { import duty })+(1-\text { Corporate tax rate }) \\
& (\text { Profit in underveloped area }+ \text { Cost disadvantage }) \\
& + \text { Tax saving Depreciation }+ \text { Scrap value }
\end{aligned}
$$

\section{RESULTS}

The theoretical model developed in the Section 1 applied to the data described in Section 2. The results are given in Tables 1, 2, and 3. Table 1 gives the net present value of a project in the underdeveloped areas and developed areas under different tax options. Column 2 of Table 1 gives the net present value of a project when no tax concession is given in the underdeveloped areas. Column 3 gives the net present value when only tax holidays are granted in the underdeveloped areas. Column 4 gives the net present value of projects when firms are allowed to deduct depreciation allowances against tax liability. Column 5 gives the net present value when both tax holiday and import duty exemption are granted in the underdeveloped area, Column 6 gives the net present value when tax holidays, depreciation allowances, and import duty exemptions in the underdeveloped areas are granted. The Column 7 of the Table I shows the net present value in the developed area when no concession is given. Whereas the Column 8 of the table shows the net present value when accelerated and normal depreciation allowances are deducted from the computation.

A comparison of Columns 2 and 3 of Table 1 shows that the concession of tax holiday increases the net present value of firms, but the benefit of this concession is confined to those firms which make profits. A comparison of Columns 2 and 4 reveals if that a firm were located in the developed areas, it could have enjoyed depreciation allowances and its net present value would have increased.

A comparison of Column 3 and 4 of Table 1 shows how the concession of the tax holidays and depreciation allowances affect the net present value of a firm. This comparison shows that out of 35 cases we have analysed, 24 show that the depreciation allowances are more effective way of increasing the net present value of a project than tax holidays. Whereas 11 show the reverse. The data shows that for firms using capital intensive technology, the depreciation allowances are more generous concessions than tax holidays. Conversely the firms which use labour intensive technology benefited most from the concessions of tax holidays. The comparison of Columns 4 and 5 shows 
Table 1

Net Present Value of Projects under Different Tax Exemptions

\begin{tabular}{|c|c|c|c|c|c|c|c|}
\hline \multirow[b]{2}{*}{ Serial* } & \multicolumn{4}{|c|}{ IN UNDERDEVELOPED AREAS } & \multirow[b]{2}{*}{ NPVUDTID } & \multicolumn{2}{|c|}{ IN DEVELOPED AREAS } \\
\hline & NPVUDW & NPVUDT & NPVUDD & NPVUDTI & & NPVDEVM & NPVDEVD \\
\hline 101 & -1.08 & -1.08 & -0.38 & -1.08 & -0.38 & -0.09 & 0.41 \\
\hline 102 & 0.45 & 0.52 & 2.32 & 1.23 & 3.09 & 0.59 & 1.93 \\
\hline 103 & 3.20 & 3.45 & 4.25 & 3.45 & 4.50 & 3.39 & 4.14 \\
\hline 104 & 1.84 & 3.12 & 3.17 & 3.12 & 4.45 & 3.04 & 3.99 \\
\hline 105 & -0.21 & -0.21 & 2.94 & 1.59 & 4.74 & -0.28 & 1.97 \\
\hline 106 & 4.09 & 7.67 & 4.49 & 7.90 & 8.31 & 4.67 & 4.96 \\
\hline 107 & 10.10 & 16.36 & 17.01 & 16.47 & 23.37 & 14.37 & 19.30 \\
\hline 108 & 1.97 & 3.44 & 3.13 & 3.44 & 4.60 & 2.33 & 3.16 \\
\hline 109 & 13.33 & 21.98 & 24.00 & 21.98 & 32.64 & 17.18 & 24.80 \\
\hline 110 & 5.30 & 10.35 & 18.49 & 16.10 & 29.29 & 7.81 & 17.23 \\
\hline 111 & 24.17 & 39.28 & 69.99 & 55.66 & 101.49 & 25.97 & 58.70 \\
\hline 112 & 3.97 & 8.06 & 8.85 & 10.85 & 15.73 & 7.22 & 10.71 \\
\hline 113 & 2.01 & 2.12 & 2.01 & 2.12 & 2.12 & 2.76 & 2.76 \\
\hline 114 & -0.42 & -0.42 & 4.84 & -0.42 & 4.84 & 1.36 & 5.11 \\
\hline 115 & 4.64 & 9.89 & 15.96 & 16.36 & 27.68 & 5.11 & 13.19 \\
\hline 116 & -0.39 & -0.39 & 4.07 & -0.39 & 4.07 & 1.37 & 4.56 \\
\hline 117 & 1.16 & 1.18 & 1.16 & 1.18 & 1.18 & 1.54 & 1.54 \\
\hline 118 & 1.89 & 2.07 & 3.86 & 3.19 & 5.16 & 1.95 & 3.36 \\
\hline 119 & 0.83 & 1.44 & 2.76 & 2.16 & 4.08 & 1.05 & 2.43 \\
\hline 120 & 20.34 & 45.85 & 25.13 & 48.59 & 53.39 & 22.75 & 26.18 \\
\hline 121 & 2.72 & 6.08 & 3.17 & 6.34 & 6.78 & 2.82 & 3.14 \\
\hline
\end{tabular}


Table 1-(Continued)

\begin{tabular}{|c|c|c|c|c|c|c|c|}
\hline 122 & 0.09 & 0.21 & 3.02 & 1.88 & 4.81 & 0.45 & 2.54 \\
\hline 123 & 32.60 & 70.65 & 102.20 & 110.42 & 180.02 & 33.66 & 83.37 \\
\hline 124 & 1.46 & 1.61 & 3.74 & 1.61 & 3.88 & 1.83 & 3.46 \\
\hline 125 & 10.66 & 18.49 & 20.05 & 18.49 & 27.88 & 15.88 & 22.59 \\
\hline 126 & 6.19 & 10.97 & 25.72 & 20.69 & 40.22 & 9.21 & 23.16 \\
\hline 127 & 5.49 & 11.60 & 6.36 & 11.60 & 12.46 & 7.92 & 8.54 \\
\hline 128 & 0.77 & 1.23 & 17.66 & 10.54 & 27.44 & 1.61 & 13.68 \\
\hline 129 & 220.99 & 222.55 & 221.46 & 222.78 & 223.24 & 222.10 & 222.43 \\
\hline 130 & 0.87 & 1.17 & 0.87 & 1.17 & 1.17 & 0.93 & 0.93 \\
\hline 131 & 0.40 & 2.16 & 9.79 & 7.53 & 16.92 & 1.15 & 7.86 \\
\hline 132 & 1.39 & 3.26 & 2.65 & 3.98 & 5.24 & 1.65 & 2.55 \\
\hline 133 & 0.94 & 1.94 & 1.50 & 2.09 & 2.65 & 1.12 & 1.52 \\
\hline 134 & 3.46 & 4.83 & 3.46 & 4.83 & 4.83 & 3.57 & 3.57 \\
\hline 135 & 0.55 & 1.52 & 2.88 & 2.85 & 5.19 & 0.94 & 2.61 \\
\hline \multicolumn{4}{|c|}{$\begin{array}{l}\text { NPVUDW }=\text { When no concession is given. } \\
\text { NPVUDT }=\text { Only tax holiday is given. } \\
\text { NPVUDD }=\text { Only depreciation allowances is given. } \\
\text { NPVUDTI }=\text { Tax holidays and import duty are given. } \\
\text { NPVUDTID }=\text { Tax holidays, import duty and depreciation are given. }\end{array}$} & \multicolumn{2}{|c|}{$\begin{array}{l}\text { NPVDEVM }=\text { When no } \\
\text { NPVDEVD }=\text { When de }\end{array}$} & $\begin{array}{l}\text { is given. } \\
\text { allowances }\end{array}$ & \\
\hline
\end{tabular}

* See Appendix 1. 
Table 2

Net Present Value of Projects in Underdeveloped Areas under Different Tax Exemptions

\begin{tabular}{|c|c|c|c|c|c|c|}
\hline \multirow[b]{2}{*}{ Serial* } & \multicolumn{3}{|c|}{ WHEN NO TAX CONCESSION IS OFFERED } & \multicolumn{3}{|c|}{ WHEN ONLY TAX HOLIDAY IS OFFERED } \\
\hline & NPVDEVW & NPVUDW & TYPE & NPVDEV & NPVUD & TYPE \\
\hline 101 & -0.09 & -1.08 & 3 & 0.41 & -1.08 & 3 \\
\hline 102 & 0.59 & 0.45 & 3 & 1.93 & 0.52 & 3 \\
\hline 103 & 3.39 & 3.20 & 3 & 4.14 & 3.45 & 3 \\
\hline 104 & 3.04 & 1.84 & 3 & 3.99 & 3.12 & 3 \\
\hline 105 & -0.28 & -0.21 & 3 & 1.97 & -0.21 & 3 \\
\hline 106 & 4.67 & 4.09 & 3 & 4.96 & 7.67 & 2 \\
\hline 107 & 14.37 & 10.10 & 3 & 19.30 & 16.36 & 3 \\
\hline 108 & 2.33 & 1.97 & 3 & 3.16 & 3.44 & 2 \\
\hline 109 & 17.18 & 13.33 & 3 & 24.80 & 21.98 & 3 \\
\hline 110 & 7.81 & 5.30 & 3 & 17.23 & 10.35 & 3 \\
\hline 111 & 25.97 & 24.17 & 3 & 58.70 & 39.28 & 3 \\
\hline 112 & 7.22 & 3.97 & 3 & 10.71 & 8.06 & 3 \\
\hline 113 & 2.76 & 2.01 & 3 & 2.76 & 2.12 & 3 \\
\hline 114 & 1.36 & -0.42 & 3 & 5.11 & -0.42 & 3 \\
\hline 115 & 5.11 & 4.64 & 3 & 13.19 & 9.89 & 3 \\
\hline 116 & 1.37 & -0.39 & 3 & 4.56 & -0.39 & 3 \\
\hline 117 & 1.54 & 1.16 & 3 & 1.54 & 1.18 & 2 \\
\hline 118 & 1.95 & 1.89 & 3 & 3.36 & 2.07 & 3 \\
\hline 119 & 1.05 & 0.83 & 3 & 2.43 & 1.44 & 3 \\
\hline 120 & 22.75 & 20.34 & 3 & 26.18 & 45.85 & 2 \\
\hline 121 & 2.82 & 2.72 & 3 & 3.14 & 6.08 & 2 \\
\hline 122 & 0.45 & 0.09 & 3 & 2.54 & 0.21 & 3 \\
\hline
\end{tabular}


Table 2-(Continued)

\begin{tabular}{|c|c|c|c|c|c|c|}
\hline 123 & 33.66 & 32.60 & 3 & 83.37 & 70.65 & 3 \\
\hline 124 & 1.83 & 1.46 & 3 & 3.46 & 1.61 & 3 \\
\hline 125 & 15.88 & 10.66 & 3 & 22.59 & 18.49 & 3 \\
\hline 126 & 9.21 & 6.19 & 3 & 23.16 & 10.97 & 3 \\
\hline 127 & 7.92 & 5.49 & 3 & 8.54 & 11.60 & 2 \\
\hline 128 & 1.61 & 0.77 & 3 & 13.68 & 1.23 & 3 \\
\hline 129 & 222.10 & 220.99 & 3 & 222.43 & 222.55 & 2 \\
\hline 130 & 0.93 & 0.87 & 3 & 0.93 & 1.17 & 2 \\
\hline 131 & 1.15 & 0.40 & 3 & 7.86 & 2.16 & 3 \\
\hline 132 & 1.65 & 1.39 & 3 & 2.55 & 3.26 & 2 \\
\hline 133 & 1.12 & 0.94 & 3 & 1.52 & 1.94 & 2 \\
\hline 134 & 3.57 & 3.46 & 3 & 3.57 & 4.83 & 2 \\
\hline 135 & 0.94 & 0.55 & 3 & 2.61 & 1.52 & 3 \\
\hline \multicolumn{7}{|c|}{$\begin{array}{l}1 \text { For generated investment. } \\
2 \text { For diverted investment. } \\
3 \text { For wrong investment. }\end{array}$} \\
\hline
\end{tabular}


Table 3

Net Present Value of Projects in Underdeveloped Areas under Different Tax Exemptions

\begin{tabular}{|c|c|c|c|c|c|c|}
\hline \multirow[b]{2}{*}{ Serial* } & \multicolumn{3}{|c|}{ WHEN NO TAX CONCESSION IS OFFERED } & \multicolumn{3}{|c|}{ WHEN ONLY TAX HOLIDAY IS OFFERED } \\
\hline & NPVDEV & NPVUDTI & TYPE & NPVDEV & NPVUDTID & TYPE \\
\hline 101 & 0.41 & -1.08 & 3 & 0.41 & -0.38 & 3 \\
\hline 102 & 1.93 & 1.23 & 3 & 1.93 & 3.09 & 2 \\
\hline 103 & 4.14 & 3.45 & 3 & 4.14 & 4.50 & 2 \\
\hline 104 & 3.99 & 3.12 & 3 & 3.99 & 4.45 & 2 \\
\hline 105 & 1.97 & 1.59 & 3 & 1.97 & 4.74 & 2 \\
\hline 106 & 4.96 & 7.90 & 2 & 4.96 & 8.31 & 2 \\
\hline 107 & 19.30 & 16.47 & 3 & 19.30 & 23.37 & 2 \\
\hline 108 & 3.16 & 3.44 & 2 & 3.16 & 4.60 & 2 \\
\hline 109 & 24.80 & 21.98 & 3 & 24.80 & 32.64 & 2 \\
\hline 110 & 17.23 & 16.10 & 3 & 17.23 & 29.29 & 2 \\
\hline 111 & 58.70 & 55.66 & 3 & 58.70 & 101.49 & 2 \\
\hline 112 & 10.71 & 10.85 & 2 & 10.71 & 15.73 & 3 \\
\hline 113 & 2.76 & 2.12 & 3 & 2.76 & 2.12 & 3 \\
\hline 114 & 5.11 & -0.42 & 3 & 5.11 & 4.84 & 3 \\
\hline 115 & 13.19 & 16.36 & 2 & 13.19 & 27.68 & 2 \\
\hline 116 & 4.56 & -0.39 & 3 & 4.56 & 4.07 & 3 \\
\hline 117 & 1.54 & 1.18 & 2 & 1.54 & 1.18 & 3 \\
\hline 118 & 3.36 & 3.19 & 3 & 3.36 & 5.16 & 2 \\
\hline 119 & 2.43 & 2.16 & 3 & 2.43 & 4.08 & 2 \\
\hline 120 & 26.18 & 48.59 & 2 & 26.18 & 53.39 & 2 \\
\hline 121 & 3.14 & 6.34 & 2 & 3.14 & 6.78 & 2 \\
\hline 122 & 2.54 & 1.88 & 3 & 2.54 & 4.81 & 2 \\
\hline 123 & 83.37 & 110.42 & 2 & 83.37 & 180.02 & 2 \\
\hline
\end{tabular}


Table 3-(Continued)

\begin{tabular}{|c|c|c|c|c|c|c|}
\hline 124 & 3.46 & 1.61 & 3 & 3.46 & 3.88 & 2 \\
\hline 125 & 22.59 & 18.49 & 3 & 22.59 & 27.88 & 2 \\
\hline 126 & 23.16 & 20.69 & 3 & 23.16 & 40.22 & 2 \\
\hline 127 & 8.54 & 11.60 & 2 & 8.54 & 12.46 & 2 \\
\hline 128 & 13.68 & 10.54 & 3 & 13.68 & 27.44 & 2 \\
\hline 129 & 222.43 & 222.78 & 2 & 222.43 & 223.24 & 2 \\
\hline 130 & 0.93 & 1.17 & 2 & 0.93 & 1.17 & 2 \\
\hline 131 & 7.86 & 7.53 & 3 & 7.86 & 16.92 & 2 \\
\hline 132 & 2.55 & 3.98 & 2 & 2.55 & 5.24 & 2 \\
\hline 133 & 1.52 & 2.09 & 2 & 1.52 & 2.65 & 2 \\
\hline 134 & 3.57 & 4.83 & 2 & 3.57 & 4.83 & 2 \\
\hline 135 & 2.61 & 2.85 & 2 & 2.61 & 5.19 & 2 \\
\hline \multicolumn{7}{|c|}{$\begin{array}{l}1 \text { For generated investment. } \\
2 \text { For diverted investment. } \\
3 \text { For wrong investment. }\end{array}$} \\
\hline
\end{tabular}


that when firms in underdeveloped areas enjoyed a tax holiday and the concessions of import duty, out of 35 cases 21 still shows that the depreciation allowances are the more effective way of increasing the net present value.

The case 129 outlier in our analysis has the highest net present value does not show any variation following the changes in the tax concessions. This is due to the fact that the net present value of this firm is strongly influenced by a very high scrap value, the firm is using labour intensive technology and domestically produced machinery.

Our first comparison of Table 2 shows the net present value of a project without any fiscal concessions in the two areas. This shows how the net present value of a project will be affected by the cost advantage or disadvantage of a backward area. Cost advantage in the backward areas results from the lower cost of land or/and unskilled labour, and cost disadvantages may results from the high cost of skilled labour, electricity, or transportation. The comparison shows all projects have their net present value higher in the developed area, which implies that the cost disadvantages of the backward areas are more than their advantages. Therefore, none of the projects will be diverted from the developed areas to the underdeveloped areas without tax incentives.

Now we will discuss different scenarios of the net present value in the developed and underdeveloped areas under different fiscal concessions. The net present value in the developed area includes the effects of tax saving depreciation allowances and the corporate tax. This net present value in developed area (NPVDEVD) will be compared with the net present values of a project in underdeveloped areas under different tax options. These options include; (a) when only tax holidays are granted (NPVUDT); (b) when tax holidays and import duty exemptions are granted (NPVUDTI); and (c) when tax holidays, import duty exemption and depreciation allowances are granted (NPVUDTID).

The major finding of the analysis is that when only tax holiday is offered, none of the projects in the Gadoon Ama Zai industrial estate is a generated unit. This implies that due to the tax holidays no new investment has been generated in this industrial estate. The results show that out of 35 units studied here, only 11 are diverted units and the remaining 24 units are wrong investment. This shows that 32 percent of the units located in this industrial estate are diverted from other areas. This investment would have taken place somewhere else even in the absence of tax holidays, but has been shifted from some other place to this industrial estate because of these concessions. Therefore the concessions granted to these diverted units constitute the tax expenditure on tax holidays. The tax expenditure given on these units equal to Rs 46.5 millions. This has been computed by multiplying the profit of the diverted units by the corporate tax rate.

The same Table 3 shows that when import duty is also offered with a tax holiday, the nature of investment changes slightly. Now with a changed package of incentives 15 units have been diverted from developed areas. This shows that the wrong investment 
decision has fallen from 28 to 20 .

The last comparison of Table 4 is between the net present values of a project in the developed areas, and a project located in the underdeveloped area that enjoys three tax concessions i.e. tax holidays, import duty and depreciation allowances. This comparison shows that due to these concessions, the number of diverted units increased to 29 and number of wrong investment reduced to 6 . This shows that for 6 units the depreciation allowances given in the developed areas are more attractive than the whole package of the concessions in the underdeveloped areas.

\section{CONCLUSIONS AND POLICY IMPLICATIONS}

The analysis of Sections 3 shows that the tax holidays at a micro level have been unsuccessful in raising investment in backward areas. The results shows that none of the units is a 'generated' unit in this industrial estate. At most the incentive is successful in diverting investment between areas. This result is consistent with previous studies: Pasha and Bengali (1985); Pasha and Ismail (1988) and Azhar and Sharif (1975).

The results also show that the depreciation allowances are more effective to increase the present value than the tax holidays concession. These results gives the clear policy guideline that if the government wants to increase investment level in the underdeveloped areas, the tax laws should be amended in such a way to allow the deferral of depreciation allowances in the tax holidays areas. 
Appendices

APPENDIX 1

\begin{tabular}{lll}
\hline S.No. & \multicolumn{1}{c}{ Name of Unit } & \multicolumn{1}{c}{ Production } \\
\hline 101 & Durrani Plastic (Pvt) Ltd. & Plastic Product \\
102 & Rina Enterprises (Pvt) Ltd. & Flexible Pipe \\
103 & Margala Packages and Allied Industries. & Poly Prophiline Woven Bags \\
104 & Sharyar Yar Steel (Pvt) Ltd. & Ingot \\
105 & Yaqoob Industries (Pvt) Ltd. & Adhesive Solution \\
106 & Al-Khair Gadoon (Pvt) Ltd. & Foam \\
107 & Gandaf Steel Industries (Pvt) Ltd. & Ingot \\
108 & ACM Industries (Pvt) Ltd. & Polythene Bags \\
109 & Kaghan Ghee Mills (Pvt) Ltd. & Ghee and Soap \\
110 & Khyber Plastic and Polymers Industries (Pvt) & \\
& Ltd. & Flexible Polythene \\
111 & Saif Textiles Mills Ltd. & Yarn \\
112 & Sumiffo Plastic Industries (Pvt) Ltd. & Plastic Product \\
113 & Agro Pak (Pvt) Ltd & Polythene Bags \\
114 & Shakir Latif Industries (Pvt) Ltd. & Yarn \\
115 & Sumiffo Medical Industries (Pvt) Ltd. & Disposable Syringe \\
116 & Kohinoor Multipurpose Industries (Pvt) Ltd. & Dry Battery Cell \\
117 & Havellian Silk Mills (Pvt) Ltd & Grey Cloth \\
118 & Hi-Tech Printing (Pvt) Ltd & Poly Bags \\
119 & MKB Industries (Pvt) Ltd. & Shopping Bags \\
120 & PEL Appliance Ltd. & Deep Freezer and A.C. \\
121 & Poly Fine Printing & Paper Sack \\
122 & S. L. Hyide Industries (Pvt) Ltd & Acrylic Pops \\
123 & Gadoon Textiles Mills Ltd. & Yarn \\
124 & Effendy STEEL (Pvt) Ltd. & Billets. \\
125 & Khyber Agro (Pvt) Ltd. & Ghee and Soap \\
126 & Adil Polypropylene Products Ltd. & Shopping Bags \\
127 & Gadoon Industries (Pvt) Ltd. & Polytene Bags and Sheets \\
128 & Cherat Paper Sack Limited & Paper Bags \\
129 & Mehran Comforts (Pvt) Ltd. & Soft Foam \\
130 & Premier Alliance Industries Ltd. & A.C. \\
131 & Dye-Chemicals Industries (Pvt) Ltd & Sulphur \\
132 & Ghelli Industries (Pvt) Ltd. & Polytene Films and Tubes \\
133 & Baber Paints Industries. & Paints \\
134 & M. B. Dyes Chemical Industries. & Dyes and Chemicals \\
135 & Gifto Industries (Pvt) Ltd. & Bottles \\
\hline & & \\
& &
\end{tabular}




\section{APPENDIX 2}

\section{COMPUTATION OF NET PRESENT VALUE}

Appendix 2 gives the details of the computation of cost disadvantages of the industrial estate; computation of cost in underdeveloped area; computation of cost in developed areas; and the computation of scrap value of machinery.

\section{Computation of Cost Disadvantage of the Industrial Estate}

The cost disadvantage of the underdeveloped area is defined as the additional cost of producing and marketing goods compared to a developed area. These increase the pre-tax profitability level in the developed area as its cost advantage arises because of an already developed infrastructure and the presence of external economies. The major components of cost which results in a cost differential can be summarised as follows:

\begin{tabular}{ll}
\hline Heads & $\begin{array}{l}\text { Cost Advantage/Disadvantage } \\
\text { in Underdeveloped Area }\end{array}$ \\
\hline Land & advantage \\
Building & disadvantage \\
Skilled/Professional Labour & disadvantage \\
Unskilled Labour & advantage \\
Transport & disadvantage \\
Electricity & disadvantage \\
Raw Material & disadvantage \\
Machinery & disadvantage \\
\hline
\end{tabular}

\section{Computation of Cost in Underdeveloped Area}

In this section we will compute cost in the underdeveloped area and in the next section cost for the developed area. These costs in both developed and underdeveloped areas have been annualised.

The total cost in the underdeveloped area has been computed as follows:

- Land: $\quad$ Total value of land in 1992 multiplied by opportunity cost of capital $\left(r^{*}\right)$ which is taken $=12.5$ percent.

Annualised cost of land $=$ (value of land $) *\left(r^{*}\right)$.

- Building: Total value of buildings in 1992 multiplied by the sum of the opportunity cost and depreciation of building ( $\delta_{1}=2.5$ percent).

Annualised cost of building $=$ (value of building $) *\left(r^{*}+\delta_{1}\right)$. 
- Machinery: Total value of machinery multiplied by the sum of opportunity cost and depreciation of machinery $=\left(\delta_{2}=10\right.$ percent $)$.

Annualised cost of machinery $=($ value of machinery $) *\left(r^{*}+\delta_{2}\right)$.

- Transport: Includes total cost of transportation of inputs and outputs.

- Electricity: This is another important cost heading differential in the two areas which includes generator cost, cost of fuel and annual wages for generator operators. Its annualised cost equals.

$=\left[(\right.$ Generator cost $\left.) *\left(r^{*}+\delta_{2}\right)\right]+$ annual cost of fuel + annual wages.

- Raw Material: Total value of raw material in 1992.

- Labour: Total salary bill for 1992.

The sum of all these cost is the total annualised cost in the underdeveloped area.

\section{Computation of Cost in Developed Area}

For annualisation of these costs the same ratios as for as underdeveloped areas have been employed.

- Land $\left(\phi_{1}\right)$ : $\quad$ In order to find the value of land in the developed area we have assumed a ratio of price of land in the developed area to the price of the underdeveloped area is equal to 3 . [Source: Guide for Industrial Investment, Chamber of Commerce (1991)].

- Building $\left(\phi_{2}\right)$ : The value of buildings is assumed to be .90 of the price of building in the underdeveloped area, as transport costs are saved.

- Machinery $\phi_{3}$ : Value of machinery is assumed to be same in both areas, because we have assumed no change in the import duty, as our analysis focuses only on the impact of direct taxes. So $\phi_{3}$ $=1$.

- Transport $\phi_{4}$ : We have assumed that the project will have the same sources of raw material and same market even if it is located in the developed area. Therefore it comprises the cost of carrying raw material from different sources plus the cost of marketing output in different places.

- Labour $\phi_{5}: \quad$ Total labour cost which is the sum of the labour cost of skilled, technical and unskilled labourers. It is assumed that the labour cost in the developed area is 0.90 percent of developed area; $\phi_{5}=0.90$.

- Electricity $\phi_{6}$ : Power is provided by the government in the developed area at $1 / 3$ cost of supply in the underdeveloped area. Therefore 
the value of $\phi_{6}$ is 0.33 .

- Tubewells $\phi_{7}$ : It is assumed that public system can provide water at a third the cost of private tubewells. Therefore the value of $\phi_{7}$ is also assumed to be 0.33 .

- Raw Material $\phi_{8}$ : It is assumed that the cost of raw material remains same in both areas. Therefore, the value of $\phi_{8}$ is assumed to be 1 .

The precise calculation needs a comprehensive survey. Systems Ltd (1986) and Applied Economics Research Centre $(1986,1993)$ have conducted two major surveys which give reasonable information to compute the cost differential between areas. With the help of the survey (Ahmed, 1993) we have estimated the cost disadvantage in the industrial estate of NWFP.

\section{Computation of the Break-up Value of a Project}

The break-up value of the project in the developed area can be computed as follows:

$$
\begin{aligned}
B U V= & 0.286\left[e^{-.067(10)} \text { Total capital cost }\right] \\
& -(0.1666 * \text { debt component })
\end{aligned}
$$

In this computation the end of the time horizon $(\mathrm{L})$ is assumed to be 10 years. This is because normal annual tax depreciation for machinery is 10 percent. An earlier study by Pasha and Bengali (1985) also assumed the same scenario. A value of 12 is taken as the normal period of repayment of a loan. The capital cost will depreciate at 6.7 percent annually. The scrap value has been discounted with a factor $\mathrm{e}^{-\mathrm{rL}}$ which in our case is 0.286 because $r=0.125$ and $\mathrm{L}=10$.

In summary the cost differentials along with profits in underdeveloped areas determine profit in the developed area. These profits in developed and underdeveloped areas along with the break-up value and the capital cost of the project determine its net present value. The net present value in developed and underdeveloped areas determines the nature of investment i.e. whether investment is generated (new investment) or diverted investment. Finally the nature of the investment determines the economic estimates of tax expenditures on the concession of tax holidays. 
Appendix Table 1-A

Annualised Cost of Production in Underdeveloped Area

(Rs Million)

\begin{tabular}{|c|c|c|c|c|c|c|c|c|}
\hline Serial1 & landud & buildud & machud & trptud & powerud & vrawmtud & labourud & $\mathrm{tcost}-\mathrm{u} / \mathrm{d}$ \\
\hline 101 & 0.04 & 0.03 & 0.45 & 0.38 & 0.00 & 9.09 & 3.00 & 12.98 \\
\hline 102 & 0.17 & 0.27 & 1.20 & 0.67 & 0.00 & 3.70 & 0.70 & 6.71 \\
\hline 103 & 0.06 & 0.45 & 0.68 & 0.67 & 0.00 & 13.98 & 1.21 & 17.04 \\
\hline 104 & 0.14 & 0.33 & 0.85 & 3.12 & 0.00 & 29.04 & 1.16 & 34.65 \\
\hline 105 & 0.21 & 0.36 & 2.03 & 0.45 & 0.00 & 5.04 & 0.53 & 8.62 \\
\hline 106 & 0.12 & 0.70 & 0.26 & 1.43 & 0.00 & 20.40 & 1.90 & 24.82 \\
\hline 107 & 0.07 & 0.45 & 4.44 & 13.05 & 0.00 & 47.18 & 4.19 & 69.39 \\
\hline 108 & 0.04 & 0.35 & 0.75 & 1.14 & 0.00 & 8.41 & 0.56 & 11.24 \\
\hline 109 & 0.09 & 2.07 & 6.85 & 10.00 & 0.00 & 186.75 & 2.39 & 208.14 \\
\hline 110 & 0.20 & 2.52 & 8.48 & 8.89 & 0.00 & 88.97 & 3.89 & 112.94 \\
\hline 111 & 0.31 & 5.62 & 29.46 & 5.83 & 0.13 & 116.52 & 13.55 & 171.41 \\
\hline 112 & 0.06 & 0.53 & 3.14 & 8.56 & 0.00 & 79.40 & 1.44 & 93.12 \\
\hline 113 & 0.33 & 0.56 & 2.16 & 2.71 & 0.00 & 15.00 & 1.10 & 21.85 \\
\hline 114 & 0.05 & 1.05 & 3.38 & 0.23 & 0.00 & 0.69 & 2.80 & 8.20 \\
\hline 115 & 0.08 & 0.82 & 7.28 & 1.22 & 0.00 & 0.45 & 0.15 & 10.00 \\
\hline 116 & 0.14 & 0.62 & 2.87 & 0.76 & 0.00 & 4.06 & 1.09 & 9.54 \\
\hline 117 & 0.05 & 0.72 & 1.60 & 0.87 & 0.00 & 0.74 & 0.86 & 4.86 \\
\hline
\end{tabular}




\begin{tabular}{|c|c|c|c|c|c|c|c|c|}
\hline 118 & 0.06 & 0.35 & 1.27 & 0.19 & 0.00 & 5.11 & 0.62 & 7.59 \\
\hline 119 & 0.07 & 0.30 & 1.24 & 0.70 & 0.00 & 10.30 & 0.59 & 13.20 \\
\hline 120 & 0.90 & 3.82 & 3.08 & 30.10 & 0.00 & 181.12 & 7.71 & 226.72 \\
\hline 121 & 0.05 & 0.14 & 0.29 & 2.90 & 0.00 & 10.97 & 0.64 & 14.99 \\
\hline 122 & 0.16 & 1.30 & 1.88 & 0.78 & 0.00 & 56.10 & 5.67 & 65.90 \\
\hline 123 & 0.74 & 3.82 & 44.74 & 5.28 & 0.46 & 178.13 & 2.76 & 235.94 \\
\hline 124 & 0.04 & 0.23 & 1.46 & 1.56 & 0.01 & 6.74 & 0.45 & 10.48 \\
\hline 125 & 0.18 & 1.36 & 6.04 & 38.10 & 0.00 & 162.72 & 7.39 & 215.79 \\
\hline 126 & 0.07 & 1.50 & 12.56 & 7.02 & 0.00 & 67.48 & 6.45 & 95.07 \\
\hline 127 & 0.02 & 0.19 & 0.56 & 6.46 & 0.00 & 33.84 & 1.99 & 43.05 \\
\hline 128 & 0.18 & 1.11 & 10.86 & 32.02 & 0.00 & 65.67 & 1.08 & 110.91 \\
\hline 129 & 0.06 & 0.30 & 0.30 & 5.75 & 0.00 & 41.77 & 4.25 & 52.42 \\
\hline 130 & 0.05 & 0.39 & 0.88 & 0.26 & 0.03 & 7.50 & 0.40 & 9.50 \\
\hline 131 & 0.04 & 0.52 & 6.04 & 1.70 & 0.00 & 16.29 & 1.60 & 26.19 \\
\hline 132 & 0.03 & 0.22 & 0.81 & 0.72 & 0.01 & 120.00 & 0.18 & 121.97 \\
\hline 133 & 0.03 & 0.08 & 0.36 & 1.76 & 0.00 & 34.00 & 0.42 & 36.65 \\
\hline 134 & 0.63 & 0.75 & 3.6 & 1.01 & 0.37 & 45 & 0.78 & 52.64 \\
\hline 135 & 0.06 & 0.54 & 1.52 & 2.35 & 0.00 & 17.42 & 0.28 & 22.18 \\
\hline
\end{tabular}


Appendix Table 1-B

Annualised Cost of Production in Developed Area

\begin{tabular}{|c|c|c|c|c|c|c|c|c|}
\hline Serial1 & landda & buildda & machda & trptda & powerda & vrawmtda & labourda & tcost-D \\
\hline 101 & 0.11 & 0.03 & 0.45 & 0.12 & 0.00 & 9.09 & 2.70 & 12.50 \\
\hline 102 & 0.51 & 0.24 & 1.20 & 0.12 & 0.00 & 3.70 & 0.63 & 6.40 \\
\hline 103 & 0.19 & 0.41 & 0.68 & 0.29 & 0.00 & 13.98 & 1.09 & 16.62 \\
\hline 104 & 0.43 & 0.29 & 0.85 & 0.31 & 0.00 & 29.04 & 1.05 & 31.97 \\
\hline 105 & 0.62 & 0.32 & 2.03 & 0.13 & 0.00 & 5.04 & 0.48 & 8.61 \\
\hline 106 & 0.37 & 0.63 & 0.26 & 0.14 & 0.00 & 20.40 & 1.71 & 23.52 \\
\hline 107 & 0.22 & 0.41 & 4.44 & 3.88 & 0.00 & 47.18 & 3.77 & 59.91 \\
\hline 108 & 0.11 & 0.31 & 0.75 & 0.34 & 0.00 & 8.41 & 0.50 & 10.43 \\
\hline 109 & 0.26 & 1.86 & 6.85 & 1.71 & 0.00 & 186.75 & 2.15 & 199.58 \\
\hline 110 & 0.59 & 2.27 & 8.48 & 3.56 & 0.00 & 88.97 & 3.50 & 107.36 \\
\hline 111 & 0.93 & 5.06 & 29.46 & 3.20 & 0.04 & 116.52 & 12.19 & 167.40 \\
\hline 112 & 0.18 & 0.47 & 3.14 & 1.42 & 0.00 & 79.40 & 1.30 & 85.90 \\
\hline 113 & 0.98 & 0.50 & 2.16 & 0.57 & 0.00 & 15.00 & 0.99 & 20.20 \\
\hline 114 & 0.15 & 0.95 & 3.38 & 0.02 & 0.00 & 0.69 & 2.52 & 7.71 \\
\hline 115 & 0.23 & 0.74 & 7.28 & 0.12 & 0.00 & 0.45 & 0.14 & 8.96 \\
\hline 116 & 0.41 & 0.55 & 2.87 & 0.44 & 0.00 & 4.06 & 0.98 & 9.33 \\
\hline 117 & 0.16 & 0.65 & 1.60 & 0.09 & 0.00 & 0.74 & 0.78 & 4.02 \\
\hline 118 & 0.19 & 0.31 & 1.27 & 0.04 & 0.00 & 5.11 & 0.56 & 7.47 \\
\hline 119 & 0.20 & 0.27 & 1.24 & 0.16 & 0.00 & 10.30 & 0.53 & 12.70 \\
\hline 120 & 2.69 & 3.44 & 3.08 & 24.10 & 0.00 & 181.12 & 6.94 & 221.36 \\
\hline
\end{tabular}


Continued-

Appendix Table 1-B-(Continued)

\begin{tabular}{|c|c|c|c|c|c|c|c|c|}
\hline 121 & 0.16 & 0.12 & 0.29 & 2.65 & 0.00 & 10.97 & 0.58 & 14.77 \\
\hline 122 & 0.49 & 1.17 & 1.88 & 0.37 & 0.00 & 56.10 & 5.10 & 65.11 \\
\hline 123 & 2.23 & 3.44 & 44.74 & 2.40 & 0.15 & 178.13 & 2.49 & 233.58 \\
\hline 124 & 0.13 & 0.20 & 1.46 & 0.72 & 0.00 & 6.74 & 0.40 & 9.66 \\
\hline 125 & 0.55 & 1.23 & 6.04 & 27.00 & 0.00 & 162.72 & 6.65 & 204.18 \\
\hline 126 & 0.20 & 1.35 & 12.56 & 0.99 & 0.00 & 67.48 & 5.81 & 88.38 \\
\hline 127 & 0.05 & 0.17 & 0.56 & 1.25 & 0.00 & 33.84 & 1.79 & 37.66 \\
\hline 128 & 0.54 & 1.00 & 10.86 & 30.00 & 0.00 & 65.67 & 0.97 & 109.04 \\
\hline 129 & 0.19 & 0.27 & 0.30 & 3.61 & 0.00 & 41.77 & 3.82 & 49.96 \\
\hline 130 & 0.14 & 0.35 & 0.88 & 0.14 & 0.01 & 7.50 & 0.36 & 9.37 \\
\hline 131 & 0.11 & 0.47 & 6.04 & 0.16 & 0.00 & 16.29 & 1.44 & 24.51 \\
\hline 132 & 0.10 & 0.20 & 0.81 & 0.13 & 0.00 & 120.00 & 0.16 & 121.40 \\
\hline 133 & 0.08 & 0.07 & 0.36 & 1.35 & 0.00 & 34.00 & 0.38 & 36.24 \\
\hline 134 & 1.88 & 0.68 & 3.6 & 0.421 & 0.12 & 45 & 0.70 & 52.40 \\
\hline 135 & 0.17 & 0.49 & 1.52 & 1.46 & 0.00 & 17.42 & 0.25 & 21.31 \\
\hline
\end{tabular}


Appendix Table 1-C

Cost Disadvantages and Scrap Value in Developed and Underdeveloped Areas

\begin{tabular}{|c|c|c|c|c|c|c|}
\hline Serial1 & costdis & netprofU & tcapcost & Equity-An & DEBT1 & Scrap V. \\
\hline 101 & 0.48 & -1.40 & 2.00 & 0.25 & 0.00 & 0.57 \\
\hline 102 & 0.31 & 0.12 & 5.53 & 0.35 & 0.50 & 1.45 \\
\hline 103 & 0.42 & 0.46 & 15.00 & 0.94 & 0.50 & 3.93 \\
\hline 104 & 2.67 & 2.33 & 3.80 & 0.19 & 0.60 & 0.98 \\
\hline 105 & 0.00 & 0.14 & 9.00 & 1.13 & 0.00 & 2.57 \\
\hline 106 & 1.30 & 6.52 & 8.62 & 1.08 & 0.00 & 2.46 \\
\hline 107 & 9.48 & 11.38 & 24.53 & 1.23 & 0.60 & 6.31 \\
\hline 108 & 0.81 & 2.68 & 3.31 & 0.04 & 0.90 & 0.81 \\
\hline 109 & 8.56 & 15.73 & 30.28 & 1.55 & 0.59 & 7.81 \\
\hline 110 & 5.58 & 9.18 & 32.14 & 1.21 & 0.70 & 8.12 \\
\hline 111 & 4.01 & 27.48 & 135.87 & 6.79 & 0.60 & 34.97 \\
\hline 112 & 7.22 & 7.44 & 16.45 & 0.82 & 0.60 & 4.23 \\
\hline 113 & 1.65 & 0.20 & 9.60 & 0.59 & 0.51 & 2.51 \\
\hline 114 & 0.49 & -2.83 & 15.00 & 1.88 & 0.00 & 4.29 \\
\hline 115 & 1.04 & 9.55 & 32.85 & 1.64 & 0.60 & 8.46 \\
\hline 116 & 0.21 & -3.04 & 12.76 & 0.64 & 0.60 & 3.29 \\
\hline 117 & 0.84 & 0.03 & 7.13 & 0.89 & 0.00 & 2.04 \\
\hline 118 & 0.12 & 0.31 & 13.38 & 0.50 & 0.70 & 3.38 \\
\hline
\end{tabular}




\begin{tabular}{lrrrrrr} 
Appendix Table 1-C—-Continued) & \multicolumn{1}{l}{} \\
\hline 119 & 0.49 & 1.10 & 5.50 & 0.41 & 0.40 & 1.47 \\
120 & 5.36 & 46.39 & 13.69 & 1.71 & 0.00 & 3.92 \\
121 & 0.22 & 6.11 & 1.42 & 0.18 & 0.00 & 0.41 \\
122 & 0.79 & 0.21 & 8.35 & 0.52 & 0.50 & 2.19 \\
123 & 2.36 & 69.18 & 198.84 & 9.94 & 0.60 & 51.18 \\
124 & 0.82 & 0.26 & 6.50 & 0.33 & 0.60 & 1.67 \\
125 & 11.61 & 14.23 & 26.41 & 3.30 & 0.00 & 7.55 \\
126 & 6.70 & 8.68 & 55.80 & 2.09 & 0.70 & 14.10 \\
127 & 5.39 & 11.10 & 3.09 & 0.39 & 0.00 & 0.88 \\
128 & 1.87 & 0.85 & 48.38 & 2.96 & 0.51 & 12.66 \\
129 & 2.47 & 2.83 & 1366.15 & 170.77 & 0.00 & 390.72 \\
130 & 0.13 & 0.54 & 3.91 & 0.49 & 0.00 & 1.12 \\
131 & 1.68 & 3.21 & 26.84 & 3.36 & 0.00 & 7.68 \\
132 & 0.57 & 3.40 & 3.60 & 0.45 & 0.00 & 1.03 \\
133 & 0.41 & 1.83 & 1.61 & 0.20 & 0.00 & 0.46 \\
134 & 0.24 & 2.5 & 14.50 & 1.81 & 0.00 & 4.15 \\
135 & 0.86 & 1.76 & 6.78 & 0.85 & 0.00 & 1.94 \\
\hline
\end{tabular}




\section{REFERENCES}

Ahmed, Qazi Masood (1997) The Influence of Tax Expenditures on Non-residential Investment. Ph.D Diss., University of Bath.

Ahmed, Qazi Masood et al. (1993) The Study on the Quantification of the Tax Expenditure in Income Tax. Karachi: Applied Economic Research Centre. (Research Report No. 8.)

Azhar, B. A., and S. M. Sharif (1974) The Effects of Tax Holiday on Investment Decision: An Empirical Analysis. The Pakistan Development Review 13:4 409-432.

Mintz, Jack M. (1990) Corporate Tax Holiday and Investment. World Bank Economic Review 4:1 81-102.

Pasha, Hafiz A., and Kaiser Bengali. (1985) Impact of Fiscal Incentives on Industrialisation in Backward Areas. Pakistan Journal of Applied Economics 4:1.

Pasha, Hafiz A., and Zafar H. Ismail (1988) Determinants of Success of Industrial Estate in Pakistan. Pakistan Economic and Social Review 26:1 1-20. 